\title{
MIGRATION AND SURVIVAL OF THE HUTTERITE BRETHREN IN CENTRAL EUROPE
}

\author{
Emese BÁLINT \\ European University Institute, Florence, Italy \\ E-mail: balint.emese.z@gmail.com
}

\begin{abstract}
While the Anabaptist movement was still fluid in the early 1520 s, it soon crystallized into factions with sharp differences. Although the Moravian Anabaptists never succeeded in creating common doctrines and practices, the Central and East European experience was not merely a marginal part of the great Anabaptist story. Out of these divergent tendencies grew a strong sect that survived exile through a radical social experiment. Hutterite colonies, settled in a hostile environment, flourished for a long period while other sects disappeared within a few years. The factors that determined the advance and survival of the Hutterites point beyond religious motives. This social experiment was dependent on the integrated social structure enabling them to cope with an aggressive environment without assimilating. Various epochs of the Hutterite history show that communal life was never a uniform and perfect experience, but variants of the structure persisted in the colonies as they evolved in their local circumstances.
\end{abstract}

Keywords: Anabaptism, Hutterite, community of goods, Moravia, Hungary, Transylvania

In January 1525, the three founders of the Swiss Brethren, Georg Blaurock, Conrad Grebel and Felix Mantz baptized one another in Zürich. With this act a movement came into being that could not be stopped in spite of the imposition of the death penalty for those who accepted baptism as adults. Persecution quickly ensued, yet Anabaptism spread rapidly across Europe. From the outside it was seen as an aggregate movement and aroused the hostility of governments and theologians. Originally, the name "Wiedertäufer" was coined by the opponents of the movement, ${ }^{1}$ and referred to all Reformation-era sects, which disapproved of the practice of infant baptism and practised baptism on believing adults. True, the Swiss Brethren, the Hutterites and the Mennonites - to name only the major groups that survived the initial turmoil - grew out of the same criticism of what

${ }^{1}$ For this reason, in German-language scholarship the term "Wiedertäufer" was changed to "Täufer" after the Second World War in order to avoid the opprobrium used by their enemies. In the Anglo-Saxon tradition, the term "Anabaptist" was kept because "Baptist", although indebted to continental Anabaptism, is a term denoting an entirely distinct entity. 
seemed to be an unholy alliance of church and state, and of their high regard for Scripture and the centrality of God's grace. These major groups had certain basic beliefs in common: they all rejected the established religious practices, customs, images, an elaborate hierarchy and the Mass; they propagated adult baptism and the 'priesthood of all believers' (equality of all believers' relation to God and equality of all in Christian community); they led a disciplined way of life and practised nonconformity (Godly living) to the world (CLASEN 1972: 91-151).

From the inside, however, the Anabaptists never managed to create one single cohesive group. The interconnectedness was shattered by bitter internal conflicts that led to insurmountable divisions within the movement. These differences related to political matters such as rejecting the functions of the state, taking oaths, litigating in court or fighting in war. Eschatological matters and Christological differences also created ruptures between the groups. One of the projects dear to the Swiss Brethren was the Liebeskommunismus (sharing and caring), which stemmed from their nonconformity; the Hutterites promoted the restoration of the community of goods practised by the apostles in Jerusalem after Pentecost, while the Dutch Mennonites expressly rejected such a radical interpretation of the Christian message (STAYER 1995; FriedMANN 1953). They differed in other respects as well: the Schwertler faction of the Anabaptists in Moravia advocated the use of the sword in wars of defence and defended the payment of war taxes, while the Stäbler, the staff-bearers, stood for complete non-resistance (BENDER 1959). In addition to differences of opinion over doctrine, there was a considerable rivalry among the different Anabaptist groups in attracting members in order to turn their respective groups into sustainable initiatives.

Systematic and intense repression, especially in Switzerland, Southern Germany and Austria, drove the Anabaptist movement into isolation; nevertheless, the Mennonites of Holland and Northern Germany and the Hutterites of Moravia enjoyed significant freedom. The aim of my introductory essay is to draw a broad socio-historical background of the Anabaptists in Moravia, for whom it stood as a "Promised Land" from 1526 to 1622. Despite the fragmentation and mutual hostility of the many small Anabaptist groups, a continuous stream of religious migrants moved towards Moravia from the Tyrol and other Habsburg lands, from Southern Germany, Bavaria, Württemberg, Hesse and from Switzerland. This period coincides approximately with the first century of Habsburg rule over the lands of the Bohemian Crown (Bohemia, Moravia, Silesia and Lusatia). In 1526 the last king of Bohemia and Hungary, Louis II fell in a battle against the Turks, and his successor Archduke Ferdinand of Austria tried to make Moravia thoroughly Catholic, an endeavour in which all Habsburgs failed up to 1620. The centralizing tendencies of the Habsburg politics were met with the critical loyalty of the Moravian lords, articulated so as to defend their liberties and privileges. Accordingly, when Emperor Charles V's brother Ferdinand became Bohemian King in the autumn of 1526, the Moravian estates recognized him but required him to confirm their traditional rights, including religious freedom. The local lords, some of them Protestants, practised such a degree of religious toleration that Moravia stood out as a unique area where the exiled religious radicals could establish their communities. The first religious migrants in south-eastern Moravia were Protestants fleeing persecution to this haven of refuge, where confessional pluralism was a legal guarantee left over from the Hussite Wars (1419-1436). 
Its capacity to accommodate a large number of religious migrants (Utraquists, Bohemian Brethren, Lutherans, Calvinist, Anti-Trinitarians and Anabaptists) was the strength of Moravian religious liberty, while the fragmentation of these groups remained its weakness: the Moravian estates paid little attention to Protestant organizational unity and remained dispersed in different faiths (EBERHARD 1995). But local pride in independence and attempts at aggressive interference on the part of the government led to permanent strains between the Catholic overlords and the predominantly Protestant estates. These tensions ultimately culminated in the battle at the White Mountain in 1620. The defeat of the Protestants was followed by drastic enforcement of the Counter-Reformation, and non-Catholics faced the alternatives of conformity or emigration. In 1622 all Anabaptists had to leave Moravia (RothKegel 2007).

According to contemporary sources, at least twenty Anabaptist sects could be distinguished in this area alone (CLASEN 1972: 32); as such, my essay will also address the changing ideological character of Moravian Anabaptism by focusing on its formative years and the survival of the Hutterites, known in later periods as the Habaner/Habans. ${ }^{2}$ It will show how, under constant persecution from the outside and with numerous conflicts and schisms from the inside, the Anabaptists started exile communities that, even with millennial expectations, could offer protection to their members. This meant nothing less than building a distinctive lifestyle and developing an accompanying doctrine. The introduction will show how, over time, among the heterogeneous Anabaptist groups, the Hutterite movement acquired a stable, ideologically and structurally integrated character in the 1530s. The difficulties in the early decades of the Reformation decimated the numerous Anabaptist sects, and during the second half of the sixteenth century most of them dwindled away, while the Hutterite Brethren became the strongest and most dynamic sect in the region. Settling new communities and recruiting fresh members in large numbers was not only their new norm but also a survival technique that involved a new way of organizing religious migration. Through homogeneity, a strong identity was formed, and along with identity formation, a large number of incoming refugees could be accommodated.

By retaining their original German language, their original garments, and living in a strictly closed social organization, the Anabaptist colonies were cultural and social enclaves amidst the local population. Strict religious principles drove these groups to give up their material effects and to conceive life as earthly exile, constantly awaiting the final union with God. The reality faced by these Anabaptists was, therefore, to live in religious and social exile, since joining a refugee community involved extreme risks, abandoning property and a dramatic change of identity. Social and economic pressure in the immediate environment, as well as sporadic persecutions and two major campaigns by the imperial government in Vienna in 1535-1537, and again in 1547, radically changed the course of Hutterite history by disrupting their settlements. The communities endured severe predation by foreign armies, survived a series of forced migrations towards Eastern Europe,

\footnotetext{
2 The term "Habaner" is used only to designate those Hutterites in Hungary who under government pressure turned Catholic in the $18^{\text {th }}$ century. The name is mostly known through the pottery produced in these Anabaptist communities. It should in fact be called "Hutterite" or "Anabaptist", but the term "Haban" is well accepted in the ceramics art literature in all countries and all languages. See Horvath-KRISZTINKOVICH 2005: 4-6.
} 
first to Northern and Western Hungary and Transylvania in 1622, then into Southern Russia in 1767, and eventually to the United States and Canada, where Hutterite colonies have persisted since 1874 (SChlachta 2008; Clasen 1972: 210-297). It is precisely the failure of so many other groups that makes the Hutterite experiment so remarkable.

\section{FORMATIVE YEARS IN MORAVIA - DISSENT AND SCHISMS}

Let us go back to the beginnings of the Moravian experience in the $1520 \mathrm{~s}$. The first Anabaptist leader of note to come to Moravia was Balthasar Hubmaier. Well-trained in scholastic theology, Hubmaier received his baccalaureus biblicus in 1511 at the University of Freiburg and his doctorate in theology at the University of Ingolstadt shortly thereafter, in 1512 (ESTEP 1996: 78-98). He was first ordained as a university preacher and chaplain of the Church of the Virgin, and then became chief preacher at the new cathedral of Regensburg where he successfully rid the town of its Jewish population. In 1521 he became pastor at Waldshut where he began to embrace certain Reformation concepts. By the time of the October Disputation in Zürich (1523), he was openly championing the Swiss Reformation and began to reform the faith and order of his church in Waldshut. His reform efforts were accompanied by a vigorous writing campaign in which he set forth a form of Reformation teaching that was neither Lutheran nor Zwinglian but had an affinity with the emerging Anabaptism of Zürich and advocated believers' (adult) baptism. In 1525 Hubmaier was baptized by Wilhelm Reublin along with sixty of his parishioners and he, in turn, baptized about 300 others. The Anabaptist movement in Waldshut was short-lived because a threatened invasion by Ferdinand of Austria drove Hubmaier from the city. After imprisonment and torture in Zürich, he managed to escape, a chastened and subdued man.

In 1526 Hubmaier arrived in Moravia and found refuge in Nikolsburg (now Mikulov) situated along the trade route from Brünn (now Brno) to Vienna, on the lands owned by the Lords of Liechtenstein. The influence of Huss was still felt in the area, and Hubmaier soon won over the church leaders and two Liechtensteins, Leonhard and his nephew Johann, to believers' baptism and began a 'socially conservative, moderate and magisterial reformation' (STAYER 1991: 139-159) explicitly based upon the patronage of the Moravian nobility. As a Schwertler (of-the-sword) Anabaptist, the moderate Hubmaier believed government to be an institution ordained by God. According to the view expressed in his writings, Christians have a responsibility to support governments and pay taxes. Furthermore, he clearly stated his beliefs regarding the government's responsibility to defend the righteous, the innocent and the helpless. Moreover, he believed that Christians should take up the sword or temporal power for a just cause if ordered to do so by the ruling government (Hubmaier 1527). Although Hubmaier did not encounter resistance on the part of the local authorities in Nikolsburg, internal tensions were evident, both in matters of worship and in more fundamental questions of theology and social ethics such as ringing bells for prayers, the celebration of Sunday and the high holidays, the desacralization of the communion, and questions about predestination, election and freedom of the will (ROTHKEGEL 2007: 171-172). 
Although his radical approach was successful with the settled population of the area, Hubmaier soon found his religious establishment threatened by large numbers of Anabaptist refugees, mainly from Southern Germany and Switzerland. These refugees rallied around the travelling preacher Hans Hut who propagated chiliastic ideas (millennialism) and the community of goods (STAYER 1995: 139-141; EsteP 1996: 98-99). He bore an intensely apocalyptic message, for he encouraged his listeners to sell their worldly goods in view of Christ's return to establish his kingdom on earth at the approaching Pentecost of 1528. Much of the leadership of the Nikolsburg community, including Hubmaier, rejected communitarian ideas, but some of the community, the Gemeinschaffter (STAYER 1995: 142), held to the principle of sharing what they have with those in need (PACKULL 1995; EsTEP 1996: 99). They willingly opened their homes and shared their property with numerous destitute strangers pouring into the area. Jacob Wiedemann, a fellow exile and preacher in Hubmaier's congregation born in Swabia and baptised in Augsburg, helped the refugees introduce a self-administered mutual aid program (PACKULL 1995: 61). Hubmaier and the local Moravians in his congregation ferociously rejected Hut's anarchistic principles and held different views about the return of Christ and the place of the magistracy; Hut was therefore expelled from Moravia by Hubmaier's noble patron. Nevertheless, his ideas concerning the restoration of the community of goods and non-resistance survived.

Hans Hut's communitarian ideas were soon embraced by Wiedemann, who held that the community of goods should be a cardinal principle among New Testament Christians. Wiedemann and his group held to an extreme form of non-resistance influenced by the Swiss Brethren, even to the point of refusing to pay taxes earmarked for war against the Turks, an issue that further polarized the two camps. Wiedemann's supporters, the socalled Stäbler (of-the-staff), joined forces with Hut's followers, grafting Hut's doctrine of the sword as the exclusive prerequisite of the saints (ESTEP 1996: 98). Despite overcoming the challenge of non-resistance and communitarianism, the so-called Nikolsburg schism occurred shortly after the Austrian government arrested Hubmaier, imprisoned and then executed him in 1528. The open friction of the opposition within the Nikolsburg group and vain attempts at reconciliation compelled the Lichtenstein barons to expel Wiedemann and his party from their lands. Thus, a group of about two hundred people, not counting children, split from the Nikolsburg church and established a new congregation at Austerlitz (now Slavkov u Brna) on the manorial estates of the Kaunitz family, where they distinguished themselves by practising an early form of the community of goods.

This controversy over communitarian ideas was just one of many disagreements to follow. Several attempts at the restoration of communal practice, and disputes over the communitarian sharing of goods soon led to dissent and experimentation in Moravia. In the years to follow, all newly created communities carried Hut's legacy by tailoring a church for the commoners, and discarded Hubmaier's attempt to create a magisterial Anabaptism by securing special places for the learned and the powerful (STAYER 1991: 141). As the Nikolsburg schism anticipated and the following examples will illustrate, distinct group theologies were only developed after the schisms had occurred. People did not split away from the congregations based on their theological belief; the separatists initially emerged from practical problems related to their conceptualization and commitment to the community of goods, which practically maintained exile communities and integrated 
the refugees. Personal rivalries among leaders just added a new dimension to these problems. In spite of their divisive articles of faith, actual boundaries between these groups remained porous; the brethren could easily leave one congregation and join another. In numerous cases, brethren excluded from one community quickly joined the enemy.

The position of the Austerlitz Brethren represented a synthesis between Hut's eschatological teachings and the Biblical norm of non-resistance. To these they added a new experiment, that of the community of goods (PACKULL 1995: 61-62; EsTEP 1996: 127). They established the first settlement (Bruderhof) in which all property was held in common and imposed a rigid hierarchy upon the commune. Individual households were not at first abandoned, much emphasis was placed upon the loving, voluntary character of the whole community, and there was no uniformity of practice, let alone equality of condition among their members. Far less democratic than the other Anabaptist groups, the Stäbler in Austerlitz were assisted by preachers or elders called the 'servants of the Word' (Diener des Wortes), and by 'stewards or servants of temporal needs' (Diener der Nortdurf), all under the high-handed control of Jacob Wiedemann. They administered a school, a bakery, a bathhouse and a cotton factory. Massive waves of new immigrants were accommodated. After 1529 they advocated an organized resettlement of Anabaptists; in this fashion a group of 80-90 Anabaptist refugees from Austria and the Tyrol, especially from Sterzing (Vipiteno) and the mining city Rattenberg am Inn, joined the Austerlitz congregation (RoTHKEGEL 2007: 181-182).

Shortly after their arrival, a clash between charismatic personalities within the Austerlitz group led to open hostilities. This time the discontent was voiced by Wilhelm Reublin, a key figure of the Swiss Anabaptists, who had baptized Hubmaier in Waldshut. After he joined the Austerlitz Bruderhof in 1530, Reublin accused the elders of unequal distribution of goods and hypocrisy in their vacillating attitude toward paying the war tax, as well as of coercing young women to marry their eligible young men in order to prevent marriage with 'heathen' or non-believing wives. He also accused Wiedemann of false doctrine regarding baptism (EsTEP 1996: 130). Thus a new schism was inevitable; in 1531 Wilhelm Reublin and Jörg Zaunring, co-workers of the charismatic leader Jakob Hutter in the Tyrol, left the Austerlitz congregation together with 150 Tyrolean followers.

The new Bruderhof was started at Auspitz (now Hustopece) under the patronage of Johanka von Boskowitz, a noblewoman and abbess of the Queen's nunnery in Mariasaal near Brno. She arranged for the settlement of the Auspitz Brethren on her family domain, and not on monastic lands (THIESSEN 2009), in the vicinity of two other pacifist communitarian groups, the Philippites, with members from Silesia, and the Gabrielites, whose members had come from Swabia. The three groups forged an alliance, which most likely involved mutual aid in both spiritual and material matters. A later schism affected the loose harmony of the three groups and furthered the sixteenth-century expression of the Hutterite identity. Following bitter strife, reciprocal accusations and excommunications, the Hutterites were able to win over members of the other two groups, sometimes with large followings.

The Auspitz settlement was organized along the same communitarian lines as the Austerlitz Bruderhof, with Reublin as the Vorsteher (chief minister) who presented himself as a new Moses chosen to deliver the true followers of Christ from the bondage of 
Wiedemann. Nevertheless, opposition to the perceived failings of the Austerlitz group did not translate into a harmonious community, and internal dissent plagued this new group too. Within only a year, the leaders of the exodus would be disgraced: Wilhelm Reublin was excluded for excess of personal possessions, while his successor, Jörg Zaunring, was found guilty and expelled for tolerating his wife's adultery. After a short interim period in which the congregation was entrusted to Sigmund Schützinger from North Tyrol, who was subsequently found guilty and removed for lax discipline regarding the community of goods, the congregation found itself without a leader.

The void was filled by Schützinger's rival, Jakob Hutter, a hat maker and 'servant of the Word' from the Tyrol, who had previously mediated between the Anabaptists in Moravia and in the fairly large congregation back in Tyrol, and who took over control by transferring his leadership role and funds to Auspitz in the summer of 1533. After having secured his position of Vorsteher with great difficulty, Hutter introduced drastic reforms. He truncated the union with the Gabrielites and Philippites; 'members of these communities were no longer considered brothers or sisters', and Hutter and his supporters laid sole claim to representing the "congregation of God" in Moravia (PACKULL 1995: 232). The inability of the Brethren in Auspitz to arrive at a modus operandi had threatened the survival of the new development; thus Hutter put the Bruderhof on a firm footing by immediate reorganization, and introduced a rigid community of goods, in both production and consumption (EsTEP 1996: 132). Following a financial conflict with the abbess, the congregation transferred residence to the lands of the lord marshal of Lippe at Schackowitz/Schäkowitz (now Sakvice) just three miles away from Auspitz, and started building a large communal dwelling, the first so-called 'pigeon coop' (Taubenkobel) that stood as the symbol of heresy in one of the pamphlets of the Jesuit polemicist Christoph Fischer (FISCHER 1607). While a considerable number of dissidents left the group to join the Philipites or the Gabrielites, a large number of Tyrolean immigrants arrived, who considered Hutter as a natural leader; their preponderance in the Bruderhof, as well as their contribution to the communal treasury, strengthened Hutter's influence in the community. At the time of Hutter's violent death in 1536, the group took his name for its own, thus becoming known as an identifiable group - the Hutterites.

\section{THE HUTTERITE SYSTEM - FORGING AN IDENTITY}

As one can see, the ideological character of the Hutterites had been formed over a long period and by integrating ideas and practices from a plurality of Anabaptist movements. The most important ideological traits that would characterise the Hutterite Brethren were outlined after the Nikolsburg schism of 1528, and the Hutterites clearly owed their organizational principles to the Auspitz group in three ways. First, they represented a commoners' movement as opposed to Hubmaier's magisterial reforms; second, they continued Hut's awareness of living in 'these last dangerous times' and expected the Second Coming (Stayer 2002: 167); and finally, they lived according to the principles of non-resistance elaborated by the Swiss Brethren. Once the ideological homogeneity was shaped, they added a new experiment to this mix, the community of goods. After the formative 
years, the Hutterites managed to turn from a heterogeneous collection of radical believers or a 'heterogeneous gathering of bold apostles' (ESTEP 1996: 127) into a structurally and ideologically integrated community.

Integration, however, was achieved through nonconformity combined with a very special organizational structure. The Bruderhof was a constructed religious space where the Hutterites tried to live as true disciples of Christ. To achieve this goal, they eliminated two basic institutions of European societies: private property and family life. Voluntary converts joining the community had to hand over their earthly possessions to the communal treasury. All property was held in common and believers had no personal belongings and received everything they needed from the community - clothes, bed linen, etc. Meals were taken in common, and special provisions were ensured for the sick and for the children. Though Hutterites retained the institution of marriage, the family was practically limited to the task of procreation and marriage practices did not pay much attention to feelings. Either Hutterite elders assigned spouses to the young, or men chose from three prospective brides. Married couples had small private bed-chambers in the common house but men and women worked and ate separately. Children were separated from their parents as soon as they were weaned. Under the direction of nursery-school sisters they were cared for in large groups of two or three hundred, which were sometimes swept by illness. Following a strict system of formal instruction, children entered school at the age of two, and attended all day, the year round. At the age of five or six, children were transferred from nursery school to work under the schoolmaster. By the age of twelve, they were apprenticed in crafts. Like the 'servants of the Word', Hutterite teachers were not usually graduates of universities but ordinary people. Nevertheless, from time to time, priests were converted and served the Brethren as schoolmasters. Among the Hutterites, women were usually assigned the duty of caring for the sick and for the youth, as well as sewing and spinning, as these were exclusively female occupations.

Each individual Bruderhof was run in cooperation by a pastor and a 'servant of temporal needs'. The selection of leaders has often been described as democratic; actually elders presented the candidate, and the community accepted or acclaimed the proposed person. If there were several candidates for an office, the practice was to make decisions by lot, not by ballot (STAYER 1991: 146). The 'servant of temporal needs' administered the finances of the community, directed the community's agricultural business together with the Weinzirl (winemaker), he was responsible for safety, and his duty was to provide the newly arrived believers with clothes and beds. While commoners could not step outside the community for any reason, the 'servant of temporal needs' was the link between the Bruderhof and the outside world. He bought the necessary raw materials for the artisans and he sold the final artefacts. Finally, 'servants of temporal needs' had legal jurisdiction over Hutterite offenders (CLASEN 1972: 260-275).

Since Hutterites refused to swear oaths, they excluded themselves from the possibility of gaining municipal citizenship rights. Nor did they become regular subjects of the local lords on whose domains they lived. Instead, they entered into a contractual relationship with the aristocracy, according to which they were freed from feudal labour obligations (Hruby 1935: 1-20). They contributed to the income of their protectors with precisely determined quantities of artisanal products or other types of services. In periods of peace 
when the communities did not suffer persecution, and especially from the 'Golden Years' of the communities (1565-1591), Hutterite craftsmen concentrated on the production of luxury goods targeted especially at the aristocracy - such as coaches and wagons, shoes, leather furniture, knives and tableware, and the famous faience pottery. In the centuries following the Hutterite 'Golden Years', the production of luxury faience items became one of the trademarks of these religious settlements, not only in Moravia but also during their eastward migration to the Kingdom of Hungary and Transylvania. ${ }^{3}$ For the most part, they produced these goods to customer orders; nevertheless, their products were also sold at local fairs and supplied to the castles of the lower nobility and the houses of the wealthy bourgeoisie (KRISZTINKOVICH 1962: 9-10). Based on the wide diversity of crafts - well documented through the numerous extant Hutterite craft guild ordinances (FrIEDMANN 1956) - the Bruderhof developed an economic profile that produced everything under one roof. Such a high standard of living was ensured by profit from the crafts that Moravia became not only the 'New Jerusalem' but a centre of material well-being. The economic security and the prospect of care for widows and orphans may have further prompted some to leave their homes and join the Hutterites in Moravia, although religious incentives played an important role in emigration. Accordingly, strong waves of emigration coincided with years of high prices and famine, although the principles of brotherhood were not to everyone's liking and members often attacked the communitarian ideals (HAUDE 2007).

Among the various utopian societies in the 1520 s, the Hutterites founded a new form of society in which, apart from the leaders, all were equal and all had to do manual labour. But unlike the peasant armies of the Black Forest and Tauber valley, or the classless peasant society envisaged by Michael Gaismaier in the Tyrol (CLASEN 1972: 296), the Hutterites were far less democratic, establishing an authoritarian hierarchy. Building a new community proved to be a difficult task as individual vision and hierarchical control turned out to be limited and fragile. The governing elite lacked the capability to coerce and monopolize violence, since the ultimate sanction was 'renunciation of the peace' and outright expulsion (CLASEN 1972: 280). It was a very fragile community experiment. Authority was not based on a leader's capacity to impose rules by the exclusive means of coercion; instead it relied on the following of a critical mass of members, and their readiness not just to live by the norms but to impose them on all members and newcomers. This voluntary nature of control, based on persuasion and inculcation of values, was enormously fragile. In a highly volatile political and economic environment, the cohesion allowed by this form of control increased chances of survival. Less cohesive groups have a much weaker capacity to adjust and to fend off external shocks or intrusions. The Hutterites were the first to

\footnotetext{
${ }^{3}$ The archaeological research has documented twelve Moravian production centres, and written sources refer to three others. The most important centre, first mentioned in the Great Chronicle in 1571, was in Wätzenobis (now Vacenovice), a village on the estate of the Zerotin family. Second in size and production was the pottery centre in Tracht (now Strachotín), a market town where the Anabaptist presence is dated from 1551, while the oldest faience centre, and third in rank, was in Teickowitz (now Tavíkovice). The largest potteryproducing centres were Alexovice (now Alexowitz), Podivín (now Kostel), Přibice (now Pribitz) and Tracht with approximately 600 members. A further nine communities were middle-sized (with 300-400 members) and two small ones had 200 members. See: PAJer 2006: 135-146; PAJer 2011: 4; The Chronicle of the Hutterian Brethren: 363, 436, 577, 637-638, 657.
} 
manage to enforce a homogeneity of practice, and that is what distinguished them from other Anabaptist groups.

For a number of years the so-called 'Austerlitz experiment' became the norm in wide areas of Southern Germany, Austria and the Tyrol, lands which later provided a continuous flow of immigrants for the Hutterites. The new identity and organizational form demanded new dynamics of community building. There was no more inner fragmentation. The group had moved from a diverse to an integrated ideology, from a pluralistic social movement (GoERTZ - STAYer 2002) to an integrated social structure, and from a theologically heterogeneous to a homogeneous membership. After its identity was formed and integrated, the movement expanded rapidly by absorbing incoming persecuted refugees. New Bruderhofs were formed in various parts of Moravia following the same basic ideology, social pattern and function. The cohesive development of the Hutterite communities, built on a very strict inner organization and backed by massive migratory reinforcements, proved indispensable for the long-term survival of the Hutterites. Those Anabaptist groups in the Bohemian Lands who had remained integrated into their urban or rural social context, or who pursued a course of de-radicalization and social reintegration, were far less exposed to governmental persecution than were the Hutterian Brethren. This was evident during the two big waves of fierce persecution in 1535 and 1548 (RoTHKEGEL 2007: 198).

The first big wave of persecution took place as a consequence of the revolt of the Anabaptists in Münster (1534-1535), when the Bohemian King Ferdinand of Austria demanded the expulsion of the Hutterian Brethren with such persistence that the Moravian nobles did not dare to refuse his orders. Unlike the other Anabaptist groups in Moravia, the Hutterites used a survival strategy that proved fruitful, dividing the congregation into small groups of six to eight persons to seek employment and shelter. Bigger groups retreated into the forests and hid underground in caves. Within a decade they were able to return to their abandoned houses and even establish more communities. By the beginning of the second persecution in 1548, the Brethren had twenty-six colonies in Moravia, but the whole brotherhood was temporarily driven from Moravia during this second upsurge. For a short time they found refuge in the Kingdom of Hungary, particularly on the estates of Baron Ferenc Nyári (Franz Niary von Prantsch) in Sabatisch (Ószombat, Szobotist, now Sobotište, Slovakia) and in Deutsch-Nussdorf (Felsődiós, now Horné Orešany, Slovakia), on the estates of Peter Bakith in Holic (Holics, in German Holitsch, Weisskirchen, now Holíč, Slovakia) and Sassin (Sasvár, in German Schossberg, now Šaštín, Slovakia), as well as on the Nádasdy and Batthyány estates (Ridovics 2002; Szebeni 1998: 110). Within a short time, the Brethren established twelve congregations in the Kingdom of Hungary. After they were forced to depart from Moravia, a chronicler related, there were many 'who united with the Church, became pious, amended their lives and took upon themselves the cross' (BECK 1883: 181-186).

The end of the second major wave of persecution brought about the 'Golden Years' (1565-1591) for the Hutterites, a period that allowed the establishment of thriving new settlements. The (re)population of these new settlements required inventive techniques in bringing new members into the communities and organizing their migration to Moravia. In order to be able to fulfil the proselytizing task required of them by Jesus's Great Commission, the congregation semi-annually (usually in the spring and autumn) chose from 
the preachers a number of Brethren to perform a wide-ranging missionary service in all geographical directions, to preach the Gospel in accordance with the commandment of Christ, and to lead the converts to the 'Promised Land' of Moravia. Each missionary had his field assigned to him; thus Brethren went out to all parts of Germany (Bavaria, Würtemberg, Hesse, Thuringia, Rhineland, also Silesia and Prussia), to Switzerland, to Poland, to the Tyrol and also to Italy. The missionaries could always be found where magisterial mandates threatened the lives of the Anabaptists; they invited the persecuted families to settle in Moravia, promising toleration and the security of a large group fellowship.

Throughout this peaceful and creative period, the Hutterite brotherhood experienced growth and unhindered development. On the larger political scene, Emperor Charles V and his brother Ferdinand sought an amicable solution with the Protestants in the Treaty of Passau of 1552. With the Peace of Augsburg in 1555 and the declaration of cuius regio, eius religio, the persecution of the Anabaptists in Moravia temporarily decreased, and the Hutterite settlements could grow in an unimpeded manner. According to estimates, there were 102 colonies and twenty to thirty thousand inhabitants (CLASEN 1972: 280), but the number of Hutterites fell dramatically after the 'Golden Years', due to wars (first between the Habsburgs and the Turks, later the Thirty Years' War) as well as the plague. After 1621, when the initial Bohemian revolt had been crushed, the Anabaptists were expelled from Moravia. The Hutterites attempted to gain a reprieve but in the end they had to accept their fate. Approximately 10,000 obeyed the order and took refuge in Northern, Western and later Eastern Hungary and Transylvania where they built new communities based on the functional models of the Moravian Bruderhof. Those who remained decided to accept Catholicism rather than face the difficulties of emigration.

After this first break-up of the cohesive group, the year 1685 represented another important stage in the development of the Hutterite organizational identity: the Hutterites in Hungary dissolved their community of goods and appealed to the government to consider them as individual householders. Those in Hungary did, however, retain some communal practices: their religious life and worship services were distinctively Hutterite. The only colony among them that maintained the community of goods was the one that had been established earlier in Transylvania, at Alwintz (now Vințu de Jos, Romania), on the estates of Prince Gábor Bethlen. Prince Bethlen had invited the Hutterites in 1621 and given them a charter and later a comprehensive letter of protection (ZíGONI 2003: 149-154). The commune enjoyed religious freedom, the development of trades and protection. During the Thirty Years' War, while settlements along the Hungarian border suffered privation, this group still prospered. Over the years, this colony also suffered the consequences of the war; it lost its communitarian organization but was revitalized by an immigrant group of Carinthian Lutherans in 1755, who re-established communal living and, as a consequence of the so-called re-Catholicisation in Hungary's eastern and northern regions, carried the movement first to Wallachia and Southern Russia in 1767, and eventually to the United States and Canada, where Hutterite colonies have persisted since 1874 (Schlachta 2008). 


\section{SURVIVAL TECHNIQUES - MISSION AND MIGRATION}

With the intensification of migration of Anabaptists into Moravia, the Hutterite Brethren maintained the functionality of the Bruderhof by creating new colonies. After reaching a critical size of 200-300 members, a Bruderhof would start a new house and a small group of believers would move to the new location. Their new identity and the new organizational form allowed for extensive missionary work. According to their agreements with the protecting patrons, the Brethren had to refrain from proselytizing among the local population, thus they had to engage in missionary work that targeted distant places. This became a standard principle, as their mission activities mobilized to assemble the elect in the last days awaiting Christ's imminent return. At the same time, it proved to be a survival strategy: from the very start of the movement, in order to sustain this dynamic and a steady number of members, Hutter organized emigration from the Tyrol that provided a large part of the Anabaptist population in Moravia. Hutter's influence on both sides of the Alps turned the Brenner Pass into a constant channel of migration and mutual stimulus between the small clandestine communities (FIrPo 2009: 9-25).

Although their communities were situated in Moravia, the Hutterites were active in a larger area by systematically sending out missionaries. The 1520 s saw a lively spread of Anabaptism throughout the Austrian territories of the Habsburg Empire, especially in Tyrol and in Carinthia. In Tyrol in particular, Anabaptism was by far the strongest trend, and remained so until far into the second half of the sixteenth century, in spite of a government that ruthlessly fought all 'heretics' wherever they could be ferreted out. In the other German lands of the Empire, Hutterites generated powerful movements in Swabia and Hesse, and also sent missionaries into the Rhine valley, Bavaria and Switzerland. Claus-Peter Clasen (1972: 35-36) has identified more Hutterite immigrants from Swabia than from the Tyrol, although he estimates that the Tyroleans were more numerous in the Hutterite leadership. Only Franconia and Thuringia remained largely untouched by their influence. About four-fifths of the missionaries who were sent out were martyred, but most of their converts managed to arrive in Moravia. Once arrived, they were directed by the elders to the host community where they had to follow the procedures of integration. According to one report, newly arrived believers were sent from one community to the next until they finally came to the bishop, who assigned them to various communities. Believers from one area were not kept together but dispersed over several communities. In the 1580 s, for example, emigrants from Hesse could be found in eighteen communities and from Württemberg in no less than twenty-two. People from a single village, Urbach, were living in seven different communities (CLASEN 1972: 230).

Migration to Moravia was not on a mass scale but included a considerable number of families, sometimes neighbourhoods or a whole congregation. Following the missionary work of Francesco della Sega, who made several trips between 1559 and 1562, almost all the inhabitants of Cinto, a little borgo situated on the road between Pordenone and Portogruaro in northern Italy, converted and migrated to Pausram (now Pouzdřany) in Moravia (FIRPo 2009: 151-152). Also, large numbers of Venetians and Friulans had headed to Moravia via Capodistria and Trieste (Stella 1969: 55). Because it was dangerous, the journey was carried out in small groups called Völker. From the Tyrol, for example, these 
small groups travelled the river routes on the Inn and the Danube, and then proceeded on foot through the forests to Moravia. Missionaries were also skilled in advising the emigrants on how to get their money and property to Moravia without their rulers' knowledge (STAYER 1991: 148).

The numbers leaving were sometimes so large, or resources taken along so great, that the civil authorities took steps to stop the movement, both by counter-persuasion and by penalties, including confiscation of property and imprisonment, both of those departing and the missionaries. Persecutions could be extremely brutal. One contemporary source claimed that prior to 1530 no less than one thousand people had been executed, and that stakes were burning all along the Inn Valley in the Tyrol (CLASEN 1972: 224-232). Hutterite missionaries could always be found where magisterial mandates threatened the lives of the Anabaptists. Brothers always had epistles and tracts in their knapsack beside a small notebook in which they entered notes during their mission trips, such as information on prospective emigrants (Schlachta 2000: 43). When arrested and imprisoned by the Venetian Santo Uffizio in 1559, the missionary Giulio Gherlandi, sent from Pausram to northern Italy, carried a long list of more than forty places and contact persons to be visited during his travel (SUV, Busta 18: 2-3).

Migration to the new settlements and the networks maintained by the Hutterite missionaries were intricately intertwined. In recent years, research on migration (and ethnic communities) has increasingly regarded networks as essential sources of social organization and resource mobilization. Networks direct our attention toward a broad context of migration: to kinship groups, communities and economic activities in both countries of origin and settlement, and in between (GoLD 2005). The Hutterite case follows a process of collective transformation involving the use of old social networks to produce new ones. Instead of individual uprooting, disorganization and adjustment, with this new dimension one can see collective action and shared struggle when discussing organized migrant networks. Following the same logic, rather than wholesale importation (and subsequent degradation) of cultural traits, one can observe collective fabrication of new cultures from old materials. Further, by understanding migration as a network-based process, we are better able to emphasize its embedded quality in a series of political, ethnic, familial and communal relationships and environments. The Hutterite case is an outstanding example for understanding migration as not only the rational and economic outcome of individual agency but as an interlaced implication of a broader range of social, cultural, religious and symbolic issues.

If we see Anabaptist migration as defined by networks, one of the implications is that the integrated social structure of the Hutterite Brethren influenced and changed the types of migration. The importance of social networks becomes clearer when we stop thinking about migration as a single homogeneous experience, and start recognizing its sharply contrasting forms. A rough but useful typology distinguishes colonizing, coerced, circular, chain and career migration (Tilly 1990: 84). For our case, we can focus on two types: coerced and chain migrations. Coerced migration entails obligatory departure, forced severing of most or all ties at the origin, and little or no personal connection between the migrants and people at the destination. The first phase of Hutterite migration illustrates this well. Just to briefly recapitulate: the influx of religious refugees to Moravia resulted 
in a rather heterogeneous collective of radical believers, some of them Anabaptists, some anti-Trinitarian, and some evangelical. After several internal crises, the Hutterite movement acquired a stable character, which meant that it became ideologically and structurally integrated. This kind of homogeneity forged a strong identity, and a large number of incoming refugees could be accommodated. Coerced migration thus transformed into chain migration.

Chain migration involved sets of related individuals or households who moved from one place to another through a set of social arrangements in which people at the destination provided aid, information and encouragement to the newcomers. Because of the risky nature of moving large numbers of refugees, they also had to think of safe routes, channels to take them from the origin to the destination. Newcomers were received under pressure to obey Hutterite rules; accordingly, they had to give up their possessions and the family-centred life that they had been previously practising. Once in Moravia, the groups were integrated into the existing colonies, some prosperous, others almost extinct, and yet others completely new. From this point on, the identity of the refugees was formed by the integrating force of the religion. They left Tyrol as Anabaptists (whatever that vague term meant) and in Moravia became Hutterites with very well defined internal rules and moral conduct.

\section{SURVIVAL TECHNIQUES - WRITING THE FAITH}

While the Anabaptist movement in Moravia was still fluid in the 1520 s, the crystallization of the Hutterite faction ushered in a different strategy that was equally important for the survival of the group. By writing the history of their movement, the Hutterites distinguished themselves among the other Anabaptist groups. The bishop (Vorsteher) of the entire brotherhood (Gemeinde) had a very important role in keeping the community together, to strengthen the identity and cohesion of the group. Alongside his spiritual and temporal duties, the bishop conducted an elaborate correspondence of the brotherhood, mainly with the missionaries abroad and with those who were held in captivity. With the epistles (Sendbriefe), he had to comfort all who suffered tribulation and affliction. Francesco della Sega, the Hutterite missionary imprisoned and tortured in Venice, received a letter from his bishop in Moravia written in Italian, his mother tongue (SzEBENI 1998: 85-86).

Furthermore, the bishop oversaw the observance of the inner discipline of the church, and wrote down the essential regulations and ordinances of the brotherhood to serve as a permanent standard. In particular the Vorsteher Andreas Ehrenpreis (1639-1662 in Sabatisch) excelled in this activity, collecting old orders and adding new ones to keep the brotherhood in good condition (LOSERTH - FRIEDMANN 1956). At the bishop's headquarters they seem to have kept orderly archives where all material of significance was collected; incoming and outgoing epistles, official writings, doctrinal statements, records about martyrs, records about the affairs of the brotherhood itself, notes on weather and prices of farm products, regulations, and elders' speeches. Many such archival sources have been collected in the publication project by the German Society for Reformation History 
(Verein für Reformationsgeschichte) since the 1930s. The series Quellen zur Geschichten der Täufer (prior to 1940, Wiedertäufer) has published eighteen thematic volumes, and the Quellen zur Geschichten der Täufer in der Schweiz has four volumes. At present, we know of 462 Hutterite manuscripts that have survived and are dispersed in different collections worldwide (RAUERT - ROTHKEGEL 2011). ${ }^{4}$

Among these sources, the chronicles, which are collections of the materials found in the archive of the Vorsteher, are of great importance. These were wellsprings from which inspiration and strength could be drawn, as well as assurance that their way was the right one. The first such chronicle, the so-called Great Chronicle ${ }^{5}$ was started under the guidance of Vorsteher Peter Walpot (1565-1578). The original manuscript is no longer extant, what has survived is a copy in a bulky volume of 612 folio leaves, continuously written until 1665 when it ends abruptly with a letter of supplication to the Mennonite brethren in Holland. More than one fifth of the Great Chronicle is made up of inserts of doctrinal statements and epistles, and it also contains doctrinal material taken from proceedings of religious debates or from other documents in the archive. For instance, only the Great Chronicle has the 'Five Articles of the Greatest Disagreement between Us and the World' (1547). At the year 1571, a lengthy insert describes in detail the organization and the work of the brotherhood, a major source of our knowledge about the life of the Hutterites (FriEDMANN 1953). In the manner of annals, all important events were registered in the Chronicle: appointment and confirmation of pastors and stewards, the death of the pastors and of the 'servants of temporal needs', predation suffered by the community at the hands of different armies, loss of property, fires, as well as the purchase of new properties, 'starting new houses'.

Characteristic of this history-minded strategy of the Hutterites, the Great Chronicle has been copied several times in smaller Denkbüchlein, memorandum booklets or simply Chronicles. To a certain extent they are only excerpts from the 'larger' chronicle, omitting much of the non-annalistic material, but partly they are original works with their own (unknown, mostly oral) sources. They partly overlap and have the same contents, but they also bring new data otherwise not available, thereby enriching our knowledge in many details. Most of these chronicles continue their story almost to the end of the seventeenth century, several authors working successively on them, similar to the way the Great Chronicle was composed. Nineteen such chronicles are known today; they were confiscated by the Jesuits in the eighteenth century and kept in libraries. These chronicles (codices enumerated from A to T) were combined like a mosaic and published by Josef BECK (1883).

\footnotetext{
${ }^{4}$ The special interest surrounding the Anabaptists is not a new one. Up until the 1960s there were several generations of mainly confessional researchers in Germany, Switzerland, the Netherlands, the United Kingdom, Canada and the United States, who studied currents in the German Reformation. More recently, "postconfessional" and secular scholars have studied the radicals, broadening religious issues and focusing on the social context and on the history of practice. A third generation of interpreters are bringing more weight to religious motives behind Reformation radicalism (STAYER 2007).

${ }^{5}$ Geschichts-Buch und kurzer Durchgang vom Anfang der Welt . . , also called Unser Gemain GeschichtBuch. The manuscript was published by Rudolf Wolkan (1923), and a critical edition was published by A. J. F. Ziegelschmid (1943).
} 
There was no such continuation during the years of decline. After about 130 years, Bishop Johannes Waldner decided to write a sequel to the first chronicle, and recorded events from 1793 to 1802 . He called the new chronicle Denkwürdigkeiten (memorabilia), and first repeated briefly the entire story of the former book with new and significant additions, then carried the story forward from the year 1665 to the moment when the Carinthian migrants joined the nearly extinct brotherhood in Transylvania around 1755 (taking his material from written and oral sources otherwise unknown). The new book, now called the Small Chronicle, consists of 370 folio leaves. ${ }^{6}$

Although the Moravian Anabaptists never succeeded in creating common doctrines and practices and their descendants have remained divided to this day, the Moravian experience was not merely a marginal part of the great Anabaptist story. Out of these divergent tendencies grew a strong sect that managed to survive exile through a radical social experiment and by building resource-providing solidarity and trust. The Hutterite colonies flourished for a long period while other sects disappeared within a few years. The factors that determined the advance and survival of the Hutterites point beyond religious motives. Staying together to survive better was a successful practice only in case of a single cohesive group. Nevertheless, cohesion did not come naturally but needed the strong intervention of several powerful leaders, who added ideology-based social components until its religious profile and identity was forged. Settled in a hostile environment, the most distinctive feature in the Hutterites' profile was their model of control through the community of goods. Between 1527 and 1533 a series of conflicts and divisions led to the emergence of a distinct and unified body with a uniform faith, a homogeneous structure, uniform daily routines and standardized economic enterprises. This social experiment was dependent on their integrated social structure so they could cope with an aggressive environment and resist assimilation.

\section{BIBLIOGRAPHY}

BECK, Josef

1883: Die Geschichtsbücher der Wiedertäufer in Oesterreich-Ungarn, betreffend deren Schicksale in der Schweiz, .... und Süd-Russland in der Zeit von 1526 bis 1785. Druck von Adolf Holzhausen. Wien.

BENDER, H. S.

1959: Schwertler. In: Global Anabaptist Mennonite Encyclopedia Online. Retrieved 27 January 2014, from http://gameo.org/index.php?title=Schwertler\&oldid=111202.

CHRONICLE

1987: The Chronicle of the Hutterian Brethren vol. I-II. Translated and published by the Hutterian Brethren. Plough Publishing House, Rifton, NY.

Clasen, Claus-Peter

1972: Anabaptism. A Social History, 1525-1618. Cornell University Press. Ithaca.

EBERHARD, W.

1995: Reformation and Counterreformation in East Central Europe. In T. A. Brady Jr. - H. A. Oberman J. D. TRACY (eds): Handbook of European History 1400-1600 vol. 2. Brill, Leiden, 551-584.

${ }^{6}$ The manuscript was published by A. J. F. ZIEGELSChmid (1947). Recently, the English translations of the Ziegelschmid editions of the Great Chronicle and of the Small Chronicle were published by the Hutterian Brethren. 
Estep, William R.

1996: The Anabaptist Story. An Introduction to Sixteenth-Century Anabaptism. William B. Eerdmans Publishing Company, Grand Rapids, MI.

FIRPo, Massimo

2009: Riforma protestante ed eresie nell'Italia del Cinquecento. Editori Laterza. Roma.

FISCHER, Christoph

1607: Der Hutterischen Wiedertauffer Taubenkobel, in welchem all ihr Mist, Kot und Unflat . . zu finden, auch des grossen Taubers, des Jakob Huters Leben . . angehängt. Ingolstadt.

FriedmanN, Robert

1953a: Community of Goods. In: Global Anabaptist Mennonite Encyclopedia Online. Retrieved 27 January 2014, from http://gameo.org/index.php?title=Community_of_Goods \&oldid=107329.

1953b: Hutterite Chronicles. In: Global Anabaptist Mennonite Encyclopedia Online. Retrieved 4 Feb 2014 from http://gameo.org/index.php?title $=$ Hutterite_Chronicles \&oldid $=111382$.

1956: Gemeindeordnungen (Hutterite Brethren). In: Global Anabaptist Mennonite Encyclopedia Online Retrieved 16 April 2013, from http://www.gameo.org/ encyclopedia/contents/ G4535.html

GoertZ, H-J - J.M. STAYeR

2002: Radikalität und Dissent im 16. Jahrhundert-Radicalism and Dissent in the Sixteenth Century. Duncker \& Humblot, Berlin.

GoLD, S. J.

2005: Migrant Networks: A Summary and Critique of Relational Approaches to International Migration. In M. Romero - E. Margolis (eds): The Blackwell Companion to Social Inequalities. Blackwell Publishing, Malden, MA, 257-277.

HaUde, Sigrun

2007: Gender Roles and Perspectives among Anabaptist and Spiritualist Groups. In J. D. Rотн - J. M. STAYER (eds): A Companion to Anabaptism and Spiritualism, 1521-1700. Brill, Leiden, 423-465.

Horvath, Eugene J. - Maria KRISZTINKovich

2005: A History of Haban Ceramics. A Private View. Vancouver.

Hruby, F.

1935: Die Wiedertäfer in Mähren. M. Heinsius, Leipzig.

HUBMAIER, Balthasar

1527: On the Sword. In W.R. Estep Jr. - B. de GraAf (eds): Anabaptist Beginnings (1523-1533). A Source Book. Nieuwkoop, 107-127.

KRisztinKovich, Béla

1962: Haban Pottery. Corvina Press, Budapest.

LoserTh, Johann - Robert FrIEDMANN

1956: Diener am Wort. In: Global Anabaptist Mennonite Encyclopedia Online. Retrieved 3 Feb 2014, from http://gameo.org/index.php?title=Diener_am_Wort\&oldid=106993.

PACKull, Werner O.

1995: Hutterite Beginnings. Communitarian Experiments during the Reformation. The Johns Hopkins University Press, Baltimore and London.

PAJER, Jiři

2006: Studie o novokřtěncích. Nakladatelství Etnos. Strážnice, 135-146.

2011: Anabaptist Faience from Moravia 1593-1620. Etnos Publishing, Strážnice.

RAuert, Mathias H. - Martin RothKegeL

2011: Katalog der hutterischen Handschriften und der Drucke aus hutterischem Besitz in Europa, vol. 1-2. Gütersloher Verlaghaus.

Ridovics Anna

2002: A Magyar Nemzeti Múzeum habán kerámiái a 17-18. századból. [17 $17^{\text {th }}-18^{\text {th }}$ century Haban ceramics in the Hungarian National Museum]. In: Folia Historica 23/1 (2002), 67-87.

RothKegel, Martin

2007: Anabaptism in Moravia and Silesia. In J. D. Roth - J. M. StaYer (eds): A Companion to Anabaptism and Spiritualism, 1521-1700. Brill, Leiden, 163-215.

Santo Ufficio di Venezia, Busta 18, ff. 2-3. 
SCHLACHTA, Astrid von

2000: Searching through the Nations: Tasks and Problems of Sixteenth-Century Hutterian Mission. The Mennonite Quarterly Review 74 (2000), 27-49.

2008: From the Tyrol to North America. Pandora Press, Kitchener, Ontario.

STAYER, James M.

1991: The German Peasants' War and Anabaptist Community of Goods. McGill-Queen's Press, Montreal.

1995: The Radical Reformation. In T. A. Brady JR. - H. A. OBerman - J. D. Tracy (eds): Handbook of European History 1400-1600, vol. 2. Brill, Leiden, 249-282.

2002: Anabaptists and the Sword. Wipf and Stock Publishers, Eugene, OR.

2007: Introduction. In J. D. Roth - J. M. STAYer (eds): A Companion to Anabaptism and Spiritualism, 1521-1700. Brill, Leiden, xiii-xxv.

Stella, Aldo

1969: Anabattismo e antitrinitarismo in Italia nel XVI secolo. Liviana, Padova.

SzeBenI, Olivér

1998: Anabaptisták [Anabaptists]. Magyarországi Baptista Egyház, Budapest.

THIESSEN, Victor

2009: Enclaves of Tolerance: Noble Patrons and Anabaptist Subjects to the 1560s. In A. SChUBERT - A. V. SChlachta - M. Driedger (eds): Grenzen des Taeufertums/Boundaries of Anabaptism. Gütersloher

Tilly, Charles Verlaghaus, Munich, 346-368.

1990: Transplanted Networks. In V. Yans-McLaughlin (ed.): Immigration Reconsidered. Oxford University Press, Oxford, 76-95.

WoLKAN, Rudolf

1923: Geschicht-Buch der Hutterischen Brüder. Vienna.

ZÁGONI, Jenő

2003: Hauß Buech, Darein wier Brueder zu Allwintz unser Hauß, Hof, Acker, Weingartten, Gärtten, und alle Liegende Gietter Beschreiben [...]'. Baptista Levéltár, Budapest.

Ziegelschmid, A. J. F.

1943: Die älteste Chronik der Hutterischen Brüder. Carl Schurz Memorial Foundation, Philadelphia.

1947: Das Klein-Geschichtsbuch der Hutterischen Brüder. Carl Schurz Memorial Foundation, Philadelphia, PA. 


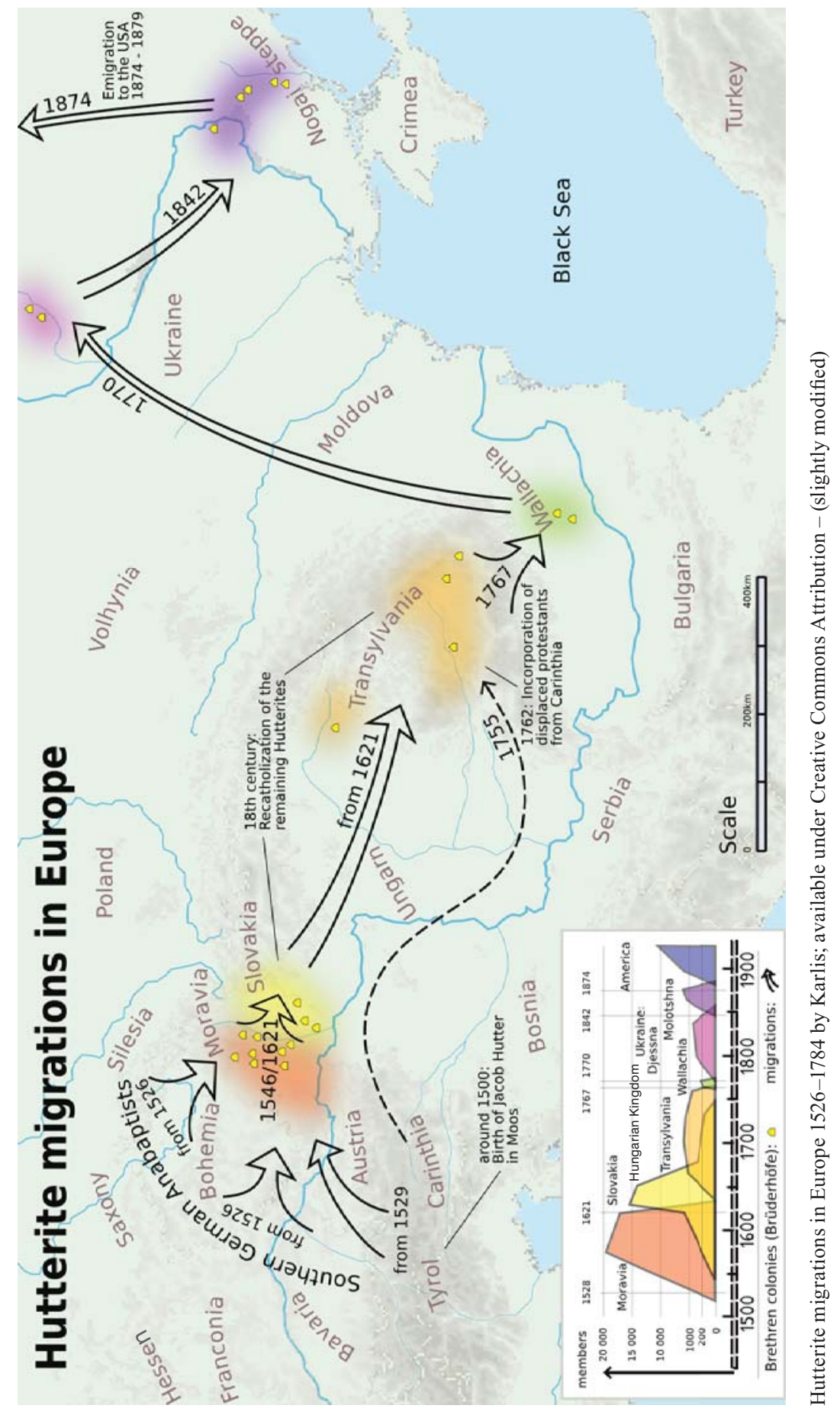



MUSEUM COLLECTIONS 
